\title{
Corrigendum: A bright and photostable photoconvertible fluorescent protein
}

Sean A McKinney, Christopher S Murphy, Kristin L Hazelwood, Michael W Davidson \& Loren L Looger

Nat. Methods 6, 131-133 (2009).

In the version of the supplementary information file originally posted online, the mitotic phases were mislabeled in Supplementary Figure 10; during amendment of the figure legend, two of the mitotic phases (metaphase and prophase) could not be tracked back to the original data. The images have been replaced, and the labeling of mitotic phases has been corrected in the supplementary information file as of 10 May 2011.

\section{Erratum: Stem cells in culture: defining the substrate} Monya Baker

Nat. Methods 8, 293-297 (2011); published online 30 March 2011; corrected after print 6 April 2011.

In the version of this article initially published, a reference was incomplete. The error has been corrected in the HTML and PDF versions of the article.

\section{Erratum: Stem cells in culture: defining the substrate} Monya Baker

Nat. Methods 8, 293-297 (2011); published online 30 March 2011; corrected after print 6 April 2011 and 16 May 2011.

In the version of this article initially published, the image descriptions were swapped. The error has been corrected in the HTML and PDF versions of the article. 